\title{
FISHERIES, EL NIÑO-SOUTHERN OSCILLATION AND UPPER-OCEAN TEMPERATURE RECORDS: AN EASTERN PACIFIC EXAMPLE
}

\author{
By Gary D. Sharp and Douglas R. McLain
}

I

T IS OFTEN RECOUNTED that the collapse of the Peruvian anchoveta fishery in the early 1970 s was a direct consequence of the El Niño of 1972-73. Comparison of time series of upper-ocean thermal data, fishery catch records, and ichthyoplankton samples from the Peruvian and northern Chilean coasts suggest that the anchoveta collapse started as early as 1968 as part of long-term ocean and atmosphere processes. These resulted in a general coastal ocean warming due to decreased upwelling of cold water along the eastern central Pacific coast, and consequent ecological changes. The ensuing 15 year coastal warming epoch culminated in the 1982-83 El Niño-Southern Oscillation (ENSO) warm event.

Although intense fishing pressure remains a major reason many fisheries ultimately become unproductive and uneconomical, fishing is usually neither the sole, nor necessarily even the primary force behind the greater fluctuations of this region's pelagic resource populations. Several recent oceanographic and ecological changes suggest that the underlying environmental variability and subsequent changes in fishery behaviors are related through ecological responses to environmental processes, whether or not exact causal mechanisms have been completely defined (Sharp, 1980; Hollowed et al., 1987; Sharp, 1988). The apparently inevitable population collapses will certainly be accelerated by intense exploitation, but fishing is not the major cause of these faunal changes observed on decadal and longer time scales (Southward et al., 1988).

This hypothesis contrasts sharply with current "environment free" stock assessment paradigms

G.D. Sharp, Cooperative Institute for Research in the Integrated Ocean Sciences, 2560 Garden Road, Monterey, CA 93940, USA. D.R. McLain, Center for Ocean Analysis and Prediction, National Oceanic and Atmospheric Administration, 2560 Garden Road, Monterey, CA 93940, USA. that do not account for observed population "outbursts," or ecological changes of the types that characterize eastern boundary currents. Similar fishery and climate records from other coastal and oceanic ecosystems are compared, and the seasonal and interannual variabilities of fisheries are related to climate processes.

\section{Historical Overview of the Fishery Catches}

The upwelling regions of eastern boundary currents in the ocean produce immense biomasses of fish that are subject to dramatic blooms and then catastrophic collapses (Sharp and Csirke, 1983; Parrish et al., 1986). One such population is the Peruvian anchoveta (Engraulis ringens) whose biomass ranged from 13 to 22 million metric tons, in Peru alone, in the late 1960s (Pauly and Tsukayama, 1987). Catches of 10-12 million tons per year were made in the early 1970 s. It has been widely asserted that the cause of the collapse of the fishery was severe over fishing exacerbated by the El Niño event of 1972-73, followed by another ENSO warming event in 1976. The Peruvian fishing fleet grew to enormous capacity, and landed record catches as product values and competition escalated. That Peruvian fleet has since dwindled and grown obsolete. The decade or more of sardine (Sardinops caerulea sagax) abundance off Chile has allowed Chilean fleets to grow and modernize, particularly in response to the recent outburst of the Chilean jack mackerel (Trachurus murphyii) resource.

The anchoveta population collapsed catastrophically from $\sim 20$ million tons biomass in the late 1960 s to $\sim 6$ million tons by 1972 . A partial recovery of the stock to $\sim 8$ million tons occurred in the early 1970 s, but then receded again in 1976 (Csirke, 1980). In subsequent years, coastal upwelling events became less intense and less frequent, catches of sardine rose to nearly 6 million tons, and the population expanded onshore and southward into northern and central
. . environmental

variability and

subsequent changes in

fishery behaviors are

related. . . 
Chile. The reports within Pauly and Tsukayama (1987) represent the "corporate memory" of the staff at Instituto del Mar del Peru (IMARPE) for the years 1953-1983. After many debates about the effects of Peru's dynamic fishery, earlier interpretations were revised and enhanced in a subsequent volume (Pauly et al., 1989).

Anchoveta abundances continued to decline through the 1982-83 ENSO warm event. Sardines flourished from the late 1960s until the mid-1980s, colonizing both northward and southward along the coast of South America. Their more oceanic habitat was previously centered at about the PeruChile border.

\section{Historical Subsurface Temperature Data}

Our major source of information on changes in the ocean's interior are profiles of subsurface temperature. Temperature measurements at discrete depth levels were made from the early 1900 s using reversing thermometers on hydrographic bottle casts. The mechanical bathythermograph (MBT) was first widely used in World War II to give a complete profile of subsurface temperature. In the mid-1960s, the expendable bathythermograph (XBT) came into common use on naval ships and later merchant ships. The ease of use of the XBT over the MBT allowed a greater number of routine thermal profile observations. Many additional profiles have been made in the last decade from conductivity-temperature-depth (CTD) profilers from research ships.

Subsurface-temperature-profile data are stored at the Fleet Numerical Oceanography Center (FNOC) in the Master Oceanographic Observations Data Set (MOODS), which is a compilation of profile data assembled from many sources, including the National Oceanographic Data Center. The typical delay in assembly of the data is about five years. The most recent update is the MOODS 5 revision from the Naval Oceanographic Office, which includes records through 1990. Data for 1991 derive from the bathythermograph (BATHY) report files at FNOC reported in near real-time by radio and satellite (McLain et al., 1986).

To describe seasonal and interannual changes of subsurface temperature along the eastern Pacific boundary, profile data were extracted from MOODS for 42 three-degree blocks of longitude and latitude along the coast from $51^{\circ} \mathrm{N}$ to $42^{\circ} \mathrm{S}$ (Fig. 1) using methods described by Brainard and McLain (1985, 1987). A time series of monthly mean depth of the $14^{\circ}$-Celsius isotherm (see cover) was developed from historical subsurfacetemperature profiles for the 49-year period 19431991 to study the changes and related ocean processes. The $14^{\circ}-\mathrm{C}$ isotherm was selected for several reasons but primarily because the depth to the $14^{\circ}-\mathrm{C}$ isotherm provides a useful indicator of the

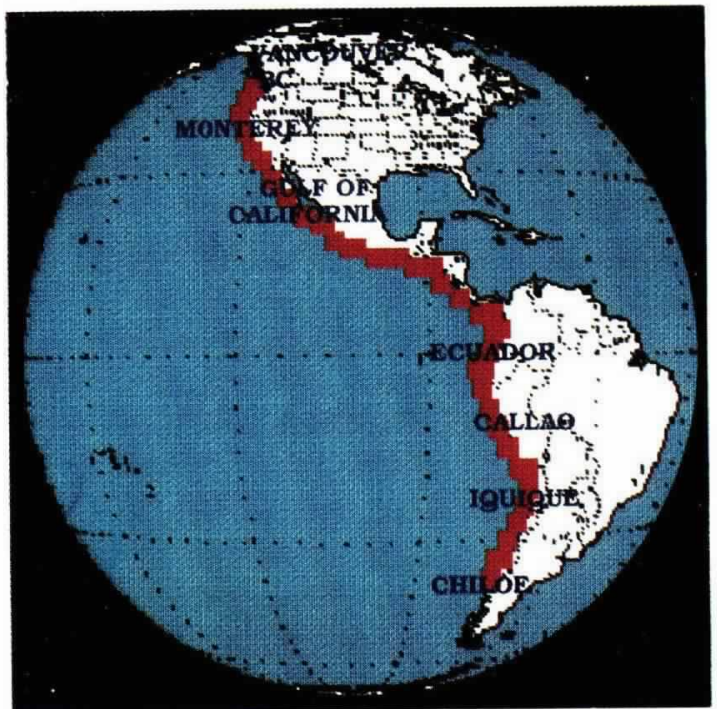

Fig. 1: The red boxes along the west coast of the Americas represent the areas from which we collated the $3^{\circ}$ latitude-longitude, monthly summaries for the depth of the $14^{\circ}-\mathrm{C}$ isotherm data shown in Figure 2. There are 42 individual cells that range from $60^{\circ} \mathrm{N}$ to $60^{\circ} \mathrm{S}$. Important fishing ports are identified.

thickness of the thermally active surface waters for much of the eastern Pacific Ocean. A composite year, labeled 1942 on the cover, comprises averaged monthly data from all years before 1943 .

The computed array of monthly mean values of $14^{\circ} \mathrm{C}$-isotherm depth is only $\sim 30 \%$ complete. Gaps in the time/area array were filled by using an interpolation scheme described in Cole and McLain (1988). The scarcity of subsurface ocean information before the 1950s is a direct indication of the recent emergence of monitoring technology and the problem of obtaining adequate continuous records. Finally the time series was colorized to show fluctuations of the isotherm depth.

\section{Changing Thermal Structure of the Coastal Eastern Pacific Ocean}

Comparison of monthly horizontal distribution for temperature at three depths (sea surface, 30 $\mathrm{m}$, and $90 \mathrm{~m}$ ) helps in the understanding of the time series on the cover. Figure 2 shows monthly mean global, $1^{\circ}$-square temperatures for the period from 1955-1985 for February and August (Robinson and Bauer, 1976). These data were compiled, and selected fields were combined for display, using SPYGLASS FORMAT visualization software. The color scale is provided to show the relative temperature distributions. Note the change in frequency distributions of SST values for each period.

The depth of the $14^{\circ}-\mathrm{C}$ isotherm along the west coast of the Americas is typically $>90 \mathrm{~m}$ from 
$\sim 21^{\circ} \mathrm{N}$ to $12^{\circ} \mathrm{S}$. The poleward surface emergence of the $14^{\circ}-\mathrm{C}$ isotherm is associated with the extensive subtropical-to-temperate transition zones within the Humboldt and California Currents. Shoaling of the isotherm characterizes localized wind-driven upwelling areas such as the Costa Rica Dome that emerge seasonally within the eastern tropical Pacific (ETP). The region of $14^{\circ} \mathrm{C}$ isotherm depths $<100 \mathrm{~m}$ extends westward along the equator and into the northern hemisphere. This reflects the strong upwelling off Peru that thins the upper-ocean thermal structure and persists over the northwestern course of the Humboldt Current. Seasonal manifestations of these different features also can be compared in Figure 2.

Off Ecuador, the $14^{\circ}-\mathrm{C}$ isotherm typically attains depths $>200 \mathrm{~m}$ in northern summer, particularly during ENSO warming phases. Note in Figure 2 that a shallow warming spreads southward from about 1970 and has no counterpart in comparable northern-latitude patterns. This is shown in the figure by blue areas that indicate $14^{\circ} \mathrm{C}$-isotherm depths of $<75 \mathrm{~m}$. The only related changes are the loss of seasonal cooling periods in the northern region after the mid- to late-1960s. as indicated by the absence of seasonal high-latitude incursions of blue colors in the figure, particularly during ENSO warm years. From this we infer that there was a general southward warming of the eastern Pacific Ocean, along with a general deepening of the isotherms, which was limited by some process in the North.

The El Niño-Southern Oscillation, as the name implies, is characterized by quasi-periodic oscillations of atmosphere and ocean processes. The extreme warm events (with low Southern Oscillation index values) are recognized as El Niño events, each of which exhibits unique development. Upper-ocean thermal structure manifestations of $\mathrm{El}$ Niños are readily observed on the cover.

High Southern Oscillation index periods are also evident as shoaling of the $14^{\circ}-\mathrm{C}$ isotherm in this record. Cool periods were the early $1950 \mathrm{~s}$. 1961-1976, 1970, 1973-1975, and 1984-1985. During 1988 to early 1990 , the ETP was in a cool phase, which is evidenced by the decreased volume of warm, tropical water in the eastern Pacific Ocean until the last half of 1990 . By mid-1990, the first phase of the recent (1991-92) ENSO warming was manifest all along the coast of the Americas as a quite usual 2-year pattern of ENSO warming that occurs several times in this record.

For over a decade Oscar Guillén, Salvador Zuta, and their colleagues at IMARPE have been trying to broaden the attention of marine scientists to include the cooler side of the ENSO phenomena, the anti-Niño or La Niña (Guillén and Calienes, 1981). Examination of the temperature record along with the records of physical conditions. climate, fisheries production, and recruitment successes show that the cool phase of ENSO ocean dynamics is as ecologically important as those of the warm phase. Zuta et al. (1984) described the dichotomy between warm El Niño waters and associated incursions of tropical species, and the anti-Niño condition of intense upwelling and shoal isotherms. Both extremes confound understanding the normal, longer-term variability of coastal species. These extreme phases of the ENSO cycle are merely exaggerations of usual seasonal patterns, within underlying longerterm trends.

For many species reproduction is delayed by a cooler habitat. More somatic growth, and therefore larger energy stores ensue, resulting in larger and more viable eggs and larvae, although perhaps fewer in total than are produced during ENSO warm events (because of thermal-stress induced spawning). Regional biological production associated with cooler, upwelling periods is suppressed by ENSO warming and related isotherm displacements.

The cover shows that the transition from the cool, 1950-1968, upwelling-dominated anchovy period, to the warm sardine-dominated regime beginning in late 1968 or so, was characterized by lesser seasonal cooling. The broadening sardine distribution corresponded nearly exactly with these changes in upper coastal-ocean heat content, and associated processes. One should not attribute the increase of sardines nor the demise of anchovies/anchoveta (Engraulis spp.) to this apparent warming, per se. Instead it is more appropriate to look into the climate-driven ocean processes that provoke these apparent changes in heat contents, such as changes in current patterns and upwelling dynamics (Norton et al., 1985). Among the many parallels of these changes in apparent heat content are the epochs of high- and lowcoastal fogs, which are the direct consequences of interactive coastal ocean dynamics and terrestrial heating as described by Bakun (1991).

Strong regional shoaling of the thermocline, or apparent heat loss, is evident during 1955, 1961$62,1971,1973-74$, and 1975-76. Also obvious are the strong 1985- and 1989-cool events that were manifest from south to north across the equator. In each of these years, surges in anchoveta abundance along the coastline of South America resulted from vigorous local upwelling events and associated coastal cooling. These local abundance surges were due to both enhanced somatic growth and enhanced survival of subsequent spawn to fishable sizes (recruitment).

Chilean data were updated through 1983 in a Chilean National Workshop Report (IFOP, 1985). Notable was the graphic by Avaria (1985) that is updated in Figure 3. The changes in distribution
. the cool phase of

ENSO ocean dynamics

is as ecologically

important as . . . the

warm phase. 



(A)

Fig. 2: SST and subsurface $(30$ and $90 \mathrm{~m})$ temperature climatologies from the Bauer and Robinson (1987) Upper Ocean Temperature Atlas have been visualized using SPYGLASS ${ }^{T M}$ software for the Macintosh. Frequency distributions of individual $1^{\circ}$-square sea-surface temperature (SST) for the global ocean also are shown. Note that there is far more warm SST in February (B) than in August (A) and that the converse is also true. The relative heat content of the Southern Hemisphere Ocean and its importance to climate cycles should be evident. Sequencing monthly climatologies has shown the relative recurrence of many recognized ocean features. The absence of strong surface features in some areas indicates that these are relatively dynamic areas, with great year-to-year variabilities. Ocean regions such as the northeast Pacific and western and central Atlantic are examples of this phenomenon. of pelagic fish production, from Peruvian coastal regions, southward into northern Chile occurred in parallel with the southward upper-ocean warming described above. Guillén and Calienes (1981) showed direct relationship between upwelling-driven primary production and Peruvian fish catch. However, recent reviews of capabilities to measure ocean primary production are unsatisfactory (Chisolm and Morel, 1991). The species composition shift from anchoveta to sardine can be associated with a general decline in local upwelling intensities and the shoreward encroachment of the warmer oceanic environment.

The decadal thermal history for the eastern $\mathrm{Pa}$ cific coast shows that over the past 30 years or so there have been several types of generic environmental changes, each associated with strong ecological responses. Among these are the recent shifts in abundance of species other than the anchoveta and sardine that have begun attracting attention. The shift of the production center for biological and fishery production southward into northern Chile stimulated industry-supported environmental monitoring in recent years. Quarterly resource surveys have been carried out since 1987 under contract by the Chilean Instituto de Fomento Pesquera (IFOP) and various university staff as coordinated and directed by industry oceanographers (J.V. Juneman and J.R. Cañon, personal communications). This collaboration has proven to be of some benefit to the industry, although the information base, which contains physical, biological, and fishery data, has not yet been released for inclusion into either national or international ocean information bases.

The general decline in upper ocean temperatures and heat content in the region since 1983 , interspersed with two extended ENSO warm periods in 1986-87 and 1990-92, provides some insights into short- and long-term behavioral changes for these fishes. During each period of increased coastal upwelling, the sardines began to change behavior. They began moving farther offshore as adults in the post-1983 cooling period. The sardine fishery continued to grow, and harvests shifted from a broad size age range to smaller, single-year classes of recruits. Today the sardine catches are in severe decline. Chile produced $<800,000$ tons in 1991, and although upwelling and associated coastal ocean cooling increased in the years after 1983, a 2-year ENSO warming event (1990-1992) is in progress.

On the other hand, in 1991, preliminary data show that anchoveta catches again attained $\sim 6$ million tons for Peru and Chile combined. Except for the interruption of this bloom by ENSO warm events, anchoveta production is expected to continue in response to progressively increasing intensity and frequency of upwelling for the next decade(s) (c.f. Sharp, 1987; Bakun, 1991). Consequently, sardine catches will continue to de- 
crease until the next phase of reduced upwelling and subsequent coastal warming.

\section{The Problem: Distinguishing Between}

Harvesting and Climate-Driven Ocean Changes in Pelagic Fish Production

The collapse of the Peruvian anchoveta fishery in the $1970 \mathrm{~s}$, along with similar collapses of other marine-fish populations elsewhere over the following decade, led to many debates. At issue is whether fishing effort or environmental change precipitates the decline in all the populations. There were dozens of workshops and conferences (e.g., Csirke and Sharp, 1983; and Sharp and Csirke, 1983). Many parallel changes in fish resources and their local environments have been documented following the model provided by Sharp, Csirke and colleagues (Bas et al., 1985; Wooster and Fluharty, 1985; Pauly et al., 1987; Payne et al., 1987; Wyatt and Larrañeta, 1988; Pauly et al., 1989; Cury and Roy, 1991; Kawasaki et al., 1991).

The environmental milieu can change rapidly, and populations can either bloom or collapse. Ecosystems are transformed in favor of species assemblages whose mere existence suggests that these oscillations are inherent, regardless of human activities. Although few if any causal relations have been defined, many speculations have been posed. Pelagic populations have inherently great reproduction potential, which, when unobstructed by intense harvests, can produce extremely large biomasses. Fishing certainly can suppress, and minimize this reproduction potential but is unlikely to explain everything, particularly the spectacular outbursts of many pelagic stocks.

Many research tacks have been taken to investigate these problems. We choose to identify climatic epochs and events within the ocean environment using the depth of the $14^{\circ}-\mathrm{C}$ isotherm. Recent efforts by Cury and Roy (1989), and many others, to examine fishery and environmental records provide the logic for identifying the direct causes. The terrestrial analogy is the record of hydrologic processes. Among the more inspired approaches have been those of the paleoclimate and paleosediment research community (e.g., Anderson, 1991). Seasonal hydrologic data have been examined to define climate variabilities from decades to several-century ecological contexts.

Centennial (or the Gleisberg cycle of 90-100 years) forcing is evident, as well as longer-scale processes. Baumgartner et al. (1989) and Soutar and Crill (1977) show evidence of even longertime-scale system-wide changes. Figure 4 shows that biomass and species oscillations occur on time scales of centuries and millennia. This type of information provokes consideration of the nested processes that must be understood. Most are manifest in serial changes for the seasonal patterns.
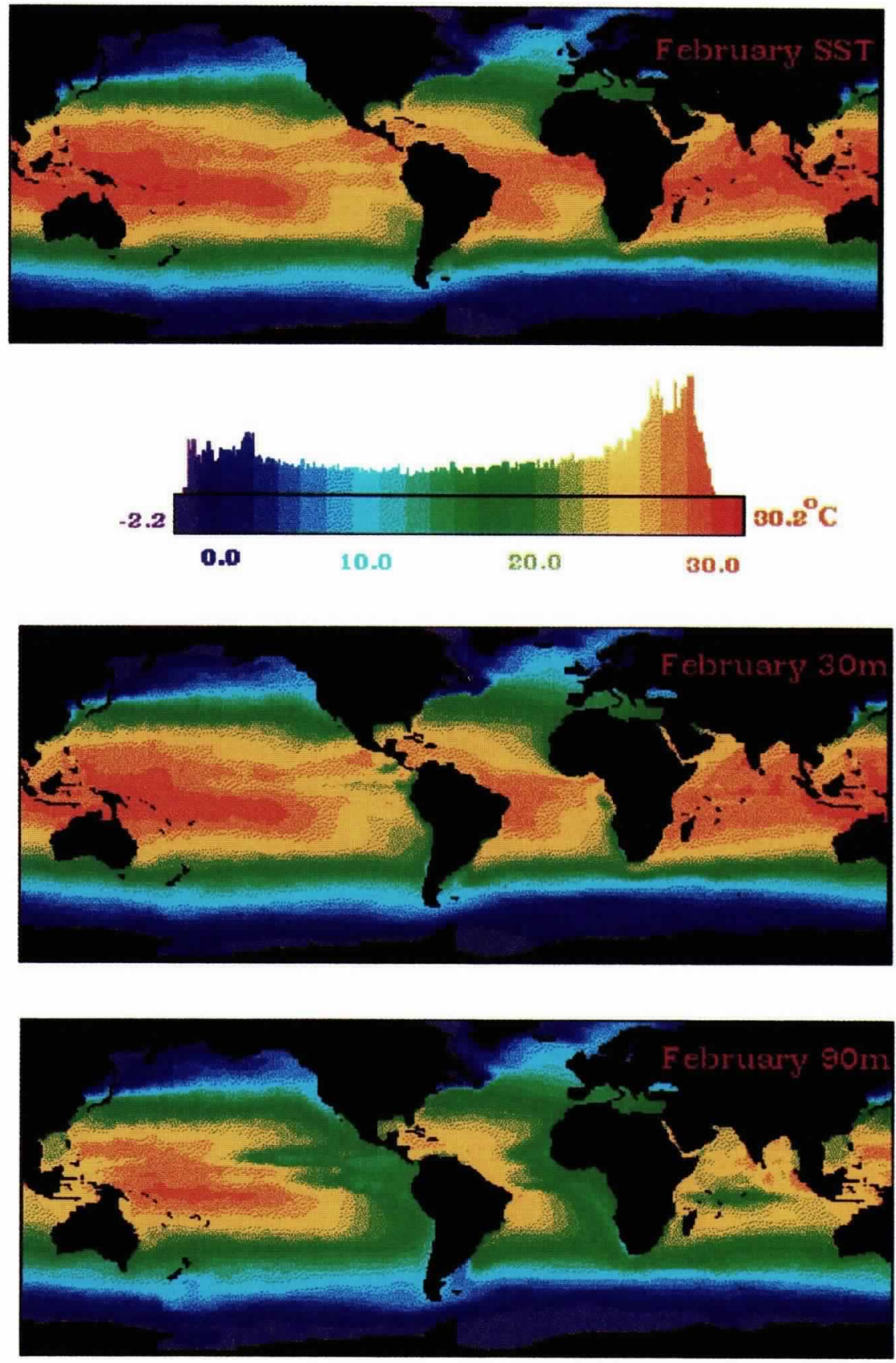

(B)

Fig. 2: Continued

\section{The Anchoveta Story: Getting the Sequence of Events Right}

Unfortunately, many misleading portrayals of the collapse of the Peruvian anchoveta have been made. The range of occurrence of anchoveta has not changed from pre-1970s abundance periods until present. Even after the population collapse, anchoveta eggs and larvae remained the most frequently encountered single fish species in the coastal waters of both Peru (Santander, 1981) and northern Chile (Loeb and Rojas, 1988). The anchoveta, although still abundant by many stan- 


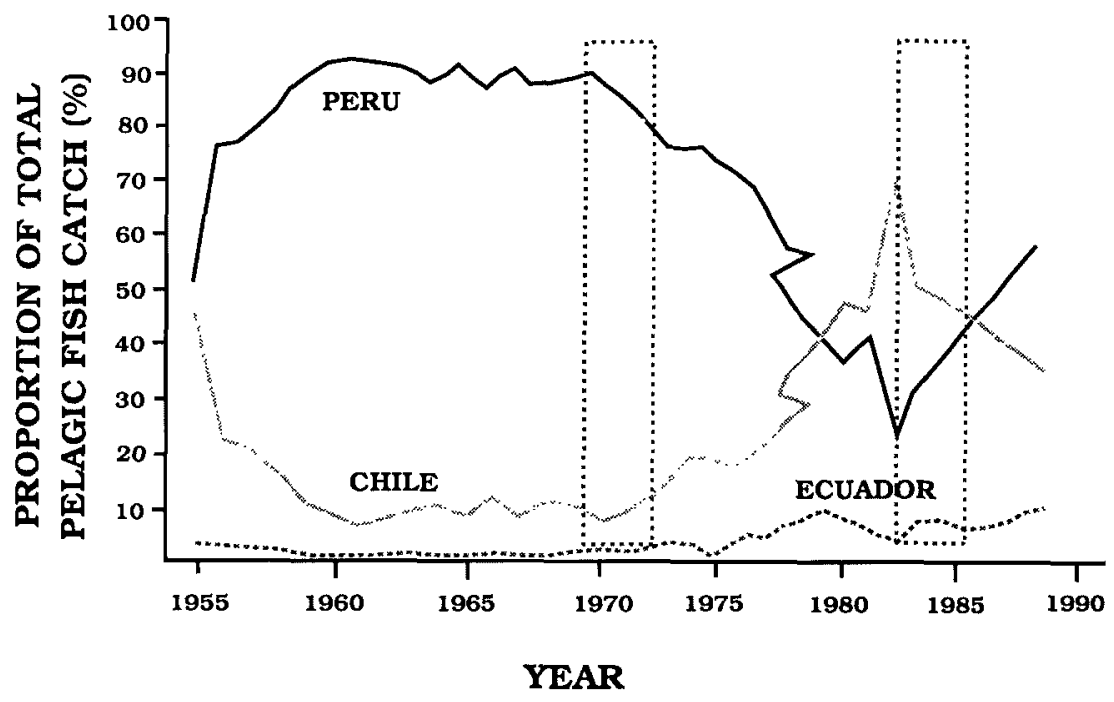

Fig. 3: Avaria (1985) summarized the changes in pelagic fish catches for Ecuador, Peru, and Chile, from 1965 to 1983. This series has been extended to 1989 and shows the reversal (after the 1982-83 ENSO warm event) of the trends in regional pelagic fish production that started in 1968-1972. Peak catches ranged from over 13 million tons (10\% of the total world fish catch) in the late 1960s to $\sim 6$ million tons in the recent years. Species composition shifted from $\sim 90 \%$ anchoveta at the catch peak, to $<10 \%$ during the mid1980 s, to $\sim 50 \%$ anchoveta at present.

The change was from coastal-upwelling

species to more

oceanic species. dards, had collapsed into many local foci of coastal upwelling, resulting from the encroachment of equatorward coastal currents onto local topographical features, each of which provides a small, dynamic refuge. These refugia, and associated anchoveta substocks, occur all along the South American coastline.

Beginning in 1968, the sardine had expanded its range to include the southern coast of Ecuador and southward to central Chile. Ecological changes, including myriad noncommercial species, occurred all along the Peruvian and Chilean coasts. The change was from the dominance of coastal-upwelling species to more oceanic species. Independent ichthyoplankton studies off western South America (Santander and Flores, 1983; Loeb and Rojas, 1988) show the steady change in species composition since the late 1960 s, preceding the 1972-73 El Niño by at least four years. These decadal changes apparently peaked with the 1982 $83 \mathrm{El}$ Niño, and subsequent upper ocean heat loss in the eastern Pacific has been dramatic. Loeb and Rojas (1988) studied available ichthyoplankton collections from Chilean research programs. They found a clear transition in the species composition of coastal ichthyofauna, beginning about 1968, from a coastal upwelling group to an offshoreoceanic fauna. Interruptions in the transition occurred in synchrony with cool-water events. Recent cooler periods have resulted in a nearly complete reversion of the coastal assemblages to well recognized coastal-upwelling species.
Interpretation of the effects from human activities is complicated. In the northern Chilean fishery, older age classes of sardines have been quite heavily exploited since 1985, and until about 1987 fish $<3$ years were rarely caught. By 1987 the adults (fish older than 3 years) had begun to move away from the coastal areas that are most accessible to the fishery. The information needed to understand this situation is complicated by the distribution of fishing activities. The spotterplanes, and therefore also the sardine fishery, operate exclusively at night. The fisheries distributions are limited by the willingness of spotter plane pilots to fly distances offshore. The pilot's decisions about whether to proceed offshore, explore, and direct fishing vessels are tempered by their concerns about safety. Their willingness declines with distance offshore.

Recent fisheries statistics from both Peru and Chile indicate that fishing mortality on sardines is steadily increasing, particularly on younger age
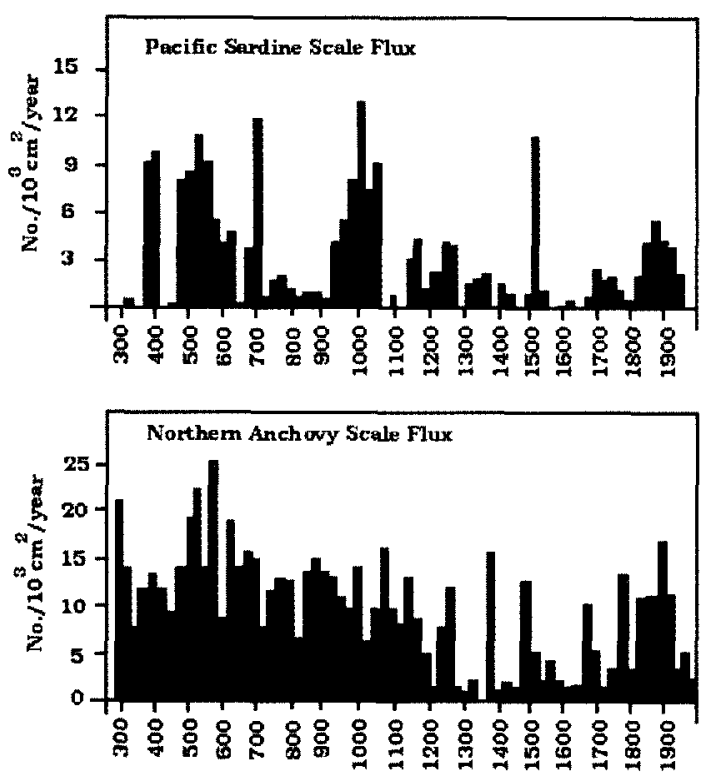

Fig. 4: The results of studies of fish debris (e.g., fish scales, otoliths, etc.) in laminated sediments from the anoxic Santa Barbara Basin (A. Soutar and T.R. Baumgartner, personal communication) are shown. Scale encounter rates for 10-vear increments have been compiled for 2.000 years for 2 pelagic species: anchovy (Engraulis) and sardine (Sardinops). These and other stratigraphic sediment data have stimulated many speculations about patterns of population and climate-related oceanographic conditions. Further sampling and studies are in progress along the west coast of the Americas and the Gulf of Mexico to complete this picture. Note the dramatic changes that occurred at $1100 \mathrm{AD}$. The anchovy record is uninterrupted. The sardine apparently disappeared from the area for periods in these records. 
classes, as the population is passing its peak abundance period (Yañez, 1991; Serra, 1991). This suggests that once again over-capitalization (overinvestment in ships and processing plants in Chile during the recent decade, as done earlier in Peru) and subsequent heavy exploitation have occurred. Unfortunately, these factors alone likely will be blamed as the sardine populations and annual catches continue to decline. Fishing is clearly not the only cause of the observed population changes.

Parallel changes in abundance and behavior of the Japanese sardine in the northwest Pacific has caused the Japanese fishery to change behavior (Kondo, 1980). In recent years Japanese fishermen have followed the larger adult fish offshore as far eastward as the International Date Line (Kawasaki et al. 1991) because their oceanic fishery does not rely on spotter planes. South American fishermen have not yet fully adapted to the changes in sardine behavior. However, the recent outburst of coastal and offshore jack mackerel resources has caused these fishermen, and their management, to rethink the problems of harvesting offshore and subsurface schools, and to reassess their approach to fisheries management.

Short-term responses to ENSO warm events have been described by several authors (Valdivia, 1978; IFOP, 1985) in terms of invasions by tropical species. For example, the recurrent appearance of Diogenichthese laternatus, a tropical lantern fish species, typifies the incursion of tropical waters (Loeb and Rojas, 1988) into northern Chile during ENSO warm events. Figure 6 shows the relation between the distribution of SST during the recent 1986-87 ENSO warming period and the occurrence of abundances for Sardinops, Engraulis, and $D$. laternatus within that region.

Ongoing environmental and consequent ecological shifts along the coast of western South America suggest that large-scale monitoring of biological systems provide direct indicators of climate variation (e.g., Sharp and McLain, 1992, this issue). Besides confirming local- and regional-scale physical environmental changes, the information is directly useful for assessing societal impactsa purpose of ENSO research (Glantz et al., 1987).

\section{Comparable Long-Term Ecological Changes Around the Globe}

There are warm oceanic epochs (not limited to ENSO warm events) that appear to last 15-20 years, when oceanic species dominate the coastal ocean, that correspond with periods when sardines (Sardinops spp.) bloom and colonize large expanses of the coastal ocean. In the intervening cooler, upwelling periods, the anchovy/anchoveta and upwelling assemblages dominate. During this century, warm epochs have been near-synchronous off the west coast of the Americas, around Japan, and also off Morocco. Figure 6 shows the concurrence of changes in sardine catches for three

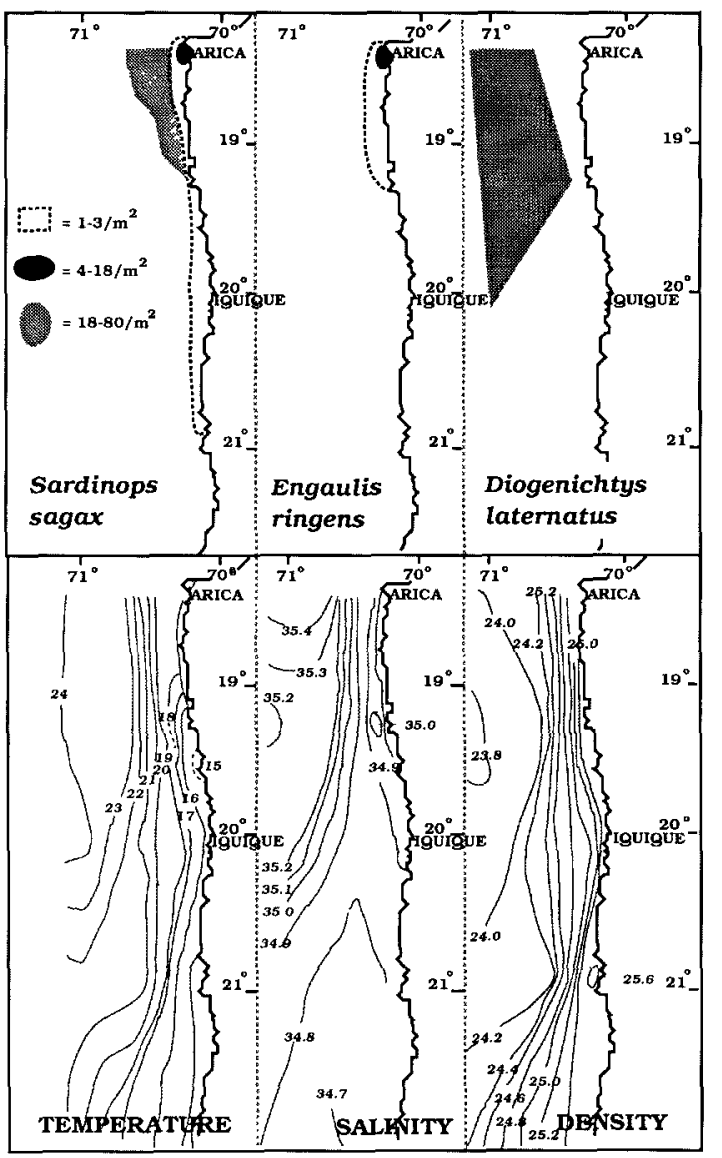

Fig. 5: Winston Palmas of the Universidad del Norte, in Iquique. Chile provided this graphic. Oceanographic and ichthyoplankton survey data from the $1983 \mathrm{El}$ Niño-Southern Oscillation warm event are plotted to show the effects of the ENSO warming. Note the very distinct distributions of the 3 species, indicating their preferences for different habitats. The densities of anchovies and sardines around Arica are a result of a persistent upwelling feature that concentrates early-life-history stages of each species. D. Laternatus has been identified as a classic indicator for eastern tropical Pacific Ocean fauna.

separate regions in the Pacific basin. However, Sardinops dominance periods off South Africa are often out of phase with those off South America. They apparently occur at higher frequencies, cycles of 20-plus years (as compared with 40 or so years for South America; Crawford et al., 1991) in response to the out-of-phase forcing from the tropical Atlantic and the Indian Ocean. The Benguela coastal ecosystem is dominated by sardine abundances, with outbursts of anchovies during decade-long periods of intense upwelling, also in contrast to the Humboldt and other easternboundary-current ecosystems.

Changes in Sardinops spp. distributions and abundances provide dramatic evidence of the coastal ocean state, in that their presence denotes
. . once again over-

capitalization . . . and

subsequent heavy

exploitation have

occurred. 


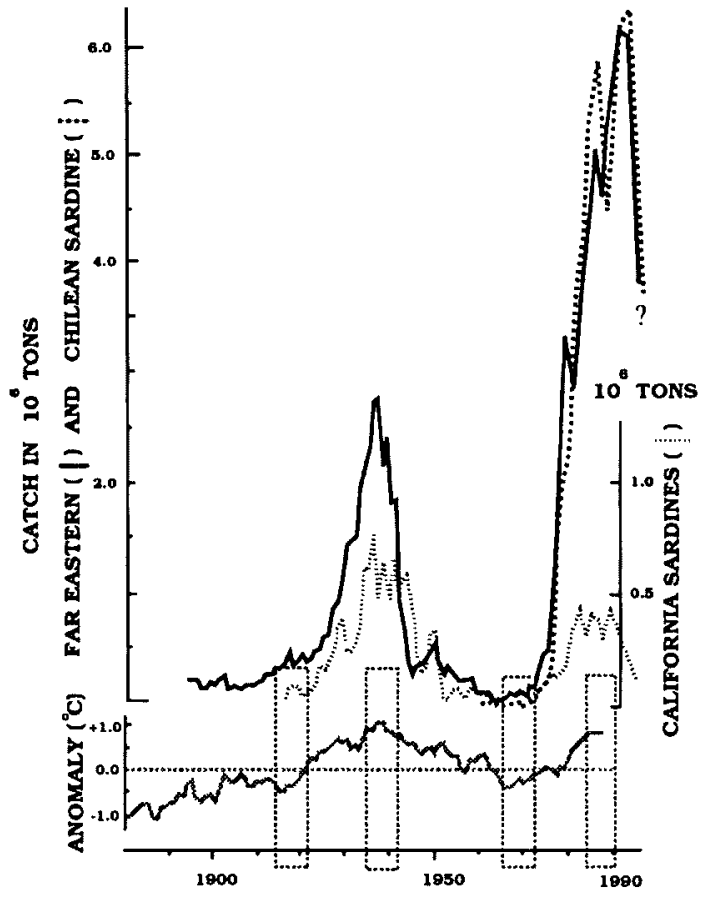

Fig. 6: Kawasaki $(1984,1991)$ provided the original time series showing the concurrent waxing and waning of Sardinops spp. in 3 isolated Pacific Ocean fisheries. This series also stimulates thought about basin-wide heating and cooling processes, and teleconnections that reach across the oceans, through ecosystems, into society. The Japanese mariculture industry is sustained by this inexpensive protein resource. Only a small fraction of the world sardine harvests are used directly for human consumption. Substitute protein sources are few, and global prices reflect these fisheries' productions. The North Pacific temperature anomaly is plotted below the catch figures.

\section{The problem with}

many fisheries studies

has been their reliance

on available SST

records . . .
Long-term changes of ocean thermal conditions and fish populations have been documented off the west coast of the Americas. Huang (1972) described a decadal shift of ocean conditions off California in the late 1950s. Moser et al. (1987) used California Cooperative Fishery Investigation (CALCOFI) data to identify several recurrent faunal groups within the California Current region. They contrasted two extreme periods, one cold and one warm, in the seven years. 19541960. These periods hinged around the 1957-59 warming, often called the El Niño of 1957-58 (Quinn et al., 1987). McLain (1983) described warming of the northeast Pacific in 1976 and Ebbesmeyer et al. (1991) described changes in 40 environmental time series from 1968 to 1984 . Like the South American region, the California Current and coastal ocean changed from a cooler, upwelling regime in the 1950 s and early 1960 s, with its associated fauna, to a warmer regime that harbors another distinctive fauna. This has been well documented, as have the extreme climatic processes associated with the stronger El Niño events, and also the longer-term warming that is only evident from longer data series (e.g., Bakun, 1991).

In fact, the reason for the development of the CALCOFI survey program in the late 1940s was the concern over California sardine fisheries. The changes off South America today likely replicate the changeover from a warm, sardine dominated California coastal fishery in the early 1940 s to a cooler, upwelling and anchovy dominated system in the 1950s. As in other eastern-boundary-current regions, many associated faunal changes have occurred during that period. The question that remains unanswered is, why?

Seemingly trivial observations, which have gone unexplained before, such as the limited spawning activity of the Peruvian anchoveta in 1970 and 1971 , probably have simple physiological explanations. The thermal profiles off South America during that period look to be in a nearly steady, cool, upwelling-dominated state. Similar responses to environmental changes have been documented by Parrish et al. (1986). Changes were observed in growth patterns for California anchovies, and other pelagic fish species in response to warm and cool thermal regimes. Clearly the importance of subsurface temperature changes to interpretations of both dramatic and subtle population changes should not be overlooked. The problem with many fisheries studies has been their reliance on available SST records as a proxy habitat variable. Individuals of many ecological components are affected by proximal conditions, and few live (i.e., spend physiologically significant time) near or at the surface of their ocean habitat.

\section{Conclusions}

Although sparse sampling makes the use of SST and monthly averages necessary in ocean climate 
studies, it is important to recognize that pelagic fish live in a dynamic multi-dimensional world, a continuum of predation and patchy feeding opportunities that has only just begun to be studied in meaningful ways. Effective monitoring of the local-scale processes that are significant to fisheries recruitment is nearly inconceivable in any but the most limited contexts. How to extrapolate these necessarily local studies to the larger population level poses many dilemmas, theoretical and real. Subsurface temperature measurements and biological information refute the presumption that the 1972-73 El Niño caused the collapse of the Peruvian anchoveta fishery.

Given the limitations of presently available technologies, we simply may never be able to afford adequate local ocean monitoring to resolve the myriad questions of cause and effect for ocean fisheries, particularly those directly affecting recruitment. However, given the historical evidence along with the perpetual changes in coastal ecosystems around the world, we suggest that if fishing were to cease today, or had even ceased five years ago, the subject sardine populations, and associated oceanic fauna would decline and collapse into local refuge areas, only to be replaced by another fauna that is supported by coastal-upwelling conditions. Intense exploitation compounds the problems and may suppress reproduction rates to levels that bring about near catastrophes, and losses of local subpopulations (Radovich, 1981; Ueber and MacCall, 1992). Understanding beyond this qualitative stage will require new techniques and involve research on many time and space scales.

\section{References}

Anderson, R.Y., 1991: The role of direct observation in predicting climatic change. In: Proceeding of the 9th Annual Pacific Climate (PACLIM) Workshop, 1991, Asilomar, California, Sacramento, 137-145.

Avaria, S., 1985: Efectos de El Niño en las pesquerias del Pacifico Sureste. Invest. Pesq. (Chile) 32, 101-116.

Bakun, A., 1991: Global climate change and intensification of coastal upwelling. Science Wash. DC, 247, 198-201.

Bas, C., R. Margalef, and P. Rubies, eds., 1985: Symposio Internacional Sobre las Areas de Afloramiento mas Importantes del Oeste Africano (Cabo Blanco y Benguela). Instituto de Investigaciones Pesqueras, Barcelona, 2 Vols., 1113 pp.

Baumgartner, T.R., J. Michaelsen, L.G. Thompson, G.T. Shen, A. Soutar, and R.E. Casey, 1989: The recording of interannual climatic change by high-resolution natural systems: tree-rings, coral bands, glacial ice layers, and marine varves. In: Aspects of Climate Variability in the Pacific and Western Americas, AGU Geophysical Monog., 55, 1-15.

Brainard, R.E. and D.R. McLain, 1985: Subsurface temperature variability along the west coast of North and South America. Tropical Ocean-Atmosphere Newsletter, 31, $1-2$.

and D.R. McLain, 1987: Seasonal and interannual subsurface temperature variability off Peru, 1951 to 1984. In: The Peruvian Anchoveta and Its Upwelling Ecosystem: Three Decades of Change. D. Pauly and I. Tsukayama, eds., ICLARM Studies and Reviews 15, Instituto del Mar del Peru (IMARPE), Callao, Peru;
Deutsche Gesellschaft fur Technische Zusammenarbeit (GTZ), GmbH, Eschborn, FRG and International Center for Living Aquatic Resources Management (ICLARM), Manila, Philippines, 14-45.

Cayan, D.R., D.R. McLain, W.D. Nichols and J.S. DiLeoStevens, 1991: Monthly Climatic Time Series Data for the Pacific Ocean and Western Americas. U.S. Geological Survey, Open File Report, 91-92.

Chisolm, S.W. and F.M.M. Morel, eds., 1991: What controls phytoplankton production in nutrient-rich areas of the open sea? American Society of Limnology and Oceanography Symposium, San Marcos, 1991, Limnol. Oceanogr., 36, $1970 \mathrm{pp.}$

Cole, D.A. and D.R. McLain, 1988: Interannual variability of temperature in the upper layer North Pacific eastern boundary region, 1971-87. NOAA/NMFS Southwest Fisheries Center, Administrative Report, La Jolla, CA.

Crawford, R.J.M., L.G. Underhill, L.V. Shannon, D. LluchBelda, W.R. Siegfried and C.A. Villacastin-Herero, 1991: An empirical investigation of trans-oceanic linkages between areas of high sardine abundance. In: Longterm Variability of Pelagic Fish Populations and Their Environment, Proceedings of the International Symposium, Sendai, Japan, 1989, Pergamon Press, Tokyo, 319-332.

Csirke, J., 1980: Recruitment in the Peruvian anchovy and its dependence upon adult population. Rapp. P.-V. Reun. Cons. Int. Explor. Mer., 177, 307-313.

and G. D. Sharp, eds., 1983: Reports of the Proceedings of the Expert Consultation to Examine the Changes in Abundance and Species Composition of Neritic Fish Resources, San Jose, Costa Rica, FAO Fish Rep., 29l(1), 100 pp.

Cury, P. and C. Roy, 1989: Optimal environmental window and pelagic fish recruitment success in upwelling areas. Can. J. Fish. Aquat. Sci., 46. 670-680.

and C. Roy, eds., 1991: Pecheres Ouest-Africaines, Variabilité, Instabilité, and Changement. Editions de l'ORSTOM, Paris, $525 \mathrm{pp}$.

Ebbesmeyer, C.C., D.R. Cayan, D.R. McLain, F.H. Nichols, D.H. Peterson and R.T. Redmond, 1991: 1976 step in the Pacific Climate: forty parameter changes between 1968-1975 and 1977-1984. In: Proceeding of the 9th Annual Pacific Climate (PACLIM) Workshop, 1991, Asilomar, California. J.L. Betancourt and V.L. Tharp, eds., Tech. Rep. Interagency Ecol. Studies Prog. Sacramento-San Joaquin Estuary. CL/PACLIM-IATR/9126. Calif. Dept. Water Resources, Sacramento, pp. 115126.

Glantz, M.H., R. Katz and M. Krenz, 1987: The Societal Impacts Associated with the 1982-83 Worldwide Climate Anomalies. National Center Atmospheric Research/ ESIG, Boulder, Colorado, $105 \mathrm{pp}$.

Guillén, O. and R. Calienes, 1981: Biological productivity and El Niño. In: Resources Management and Environmental Uncertainty: Lessons from Coastal Upwelling Fisheries. M.H. Glantz and J. Dana Thompson, eds., Wiley Interscience, New York, 255-282.

Hollowed, A.B., K.M. Bailey and W.S. Wooster, 1987: Patterns of recruitment in the northeast Pacific Ocean. Biol. Oceanogr., 5, 99-131.

Huang, J.C.K., 1972: Recent decadal variation in the California Current system. J. Phys. Oceanog., 2, 382-390.

IFOP, 1985: Taller Nacional: fenomeno El Niño 1982-83. Invest. Pesq., 32, $256 \mathrm{pp}$.

Kawasaki, T., 1984: Why do some fishes have wide fluctuations in their numbers? Biological basis of fluctuation from the viewpoint of evolutionary ecology. FAO Fish. Rep., 291, 1065-1080.

, S. Tanaka, Y. Toba and A. Taniguchi, eds., 1991: Long-Term Variability of Pelagic Fish Populations and Their Environment. Pergamon Press, Tokyo, 402 pp.

Kondo, K., 1980: The recovery of the Japanese sardine-the biology basis of stock size fluctuations. Rapp. P.-V. Reun. Cons. Int. Explor. Mer., 177, 332-352.
. . refute the

presumption that the

1972-73 El Nixoo

caused the collapse of

the Peruvian

anchoveta fishery. 
Loeb, V. and O. Rojas, 1988: Interannual variation of ichthyoplankton composition and abundance relations off northern Chile. Fish. Bull., U.S., 86, 1-24.

McLain, D.R., 1983: Coastal ocean warming in the Northeast Pacific, 1976-83. In: The Influence of Ocean Conditions on the Production of Salmonids in the North Pacific, a W'orkshop. W.G. Pearcy, ed., Oregon State University, Sea Grant College Program, ORESU-W-83:61-86. 6186.

McLain D.R., P.D. Stevens, and R.A. Bauer, 1986: Real-time reporting of ocean temperature and salinity profiles. In: Proceedings of MDS '86, Marine Data Systems International Symposium, Marine Technology Society, 527546.

Moser, H.G., P.E. Smith and L.E. Eber, 1987: Larval fish assemblages in the California Current, 1951-1960, a period of dynamic environmental change. CalCOFI Rep.. XXVIII, 97-127.

Norton, J.R., D.R. McLain, R. Brainard and D. Husby, 1985: The 1982-83 El Niño event off Baja and Alta California, and its ocean climate context. In: El Niño North: Niño Effects in the Eastern Subarctic Pacific Ocean. W.S. Wooster and D.L. Fluharty, eds., Washington Sea Grant, Seattle, 44-72.

Parrish, R.H., Mallicoate, D.L. and R.A. Klingbeil, 1986: Age dependent fecundity, number of spawnings per year, sex ratio. and maturation stages in northern anchovy. Engraulis Mordax. Fishery Bull., U.S., 84, 503-517.

Pauly, D., P. Muck, J. Mendo and I. Tsukayama, 1989: The Perwvian Upwelling Ecosystem: Dynamics and Interactions. ICLARM Conference Proceedings 18. Instituto del Mar del Peru (IMARPE), Callao, Peru; Deutsche Gesellschaft für Technische Zusammenarbeit (GTZ), GmbH. Eschbom, FRG; and International Center for Living Aquatic Resources Management, Manila, Philippines, $438 \mathrm{pp}$.

, M.L. Palomares and F.C. Gayanilo. 1987: VPA estimates of the monthly population length composition, recruitment, mortality. biomass, and related statistics of Peruvian anchoveta, 1953 to 1981. In: The Peruvian Anchoveta and Its Upwelling Ecosystem: Three Decades of Change. ICLARM Studies and Reviews 15, Instituto del Mar del Peru (IMARPE), Callao, Peru; Deutsche Gesellschaft fur Technische Zusammenarbeit (GTZ), GmbH, Eschborn, FRG and International Center for Living Aquatic Resources Management (ICLARM), Manila. Philippines, 142-178.

and I. Tsukayama, 1987: The Peruvian anchoveta and its upwelling ecosystem: three decades of change. ICLARM Studies and Reviews 15. Instituto del Mar del Peru (IMARPE), Callao. Peru; Deutsche Gesellschaft fur Technische Zusammenarbeit (GTZ), GmbH, Eschborn, FRG; and International Center for Living Aquatic Resources Management (ICLARM), Manila. Philippines, $351 \mathrm{pp}$.

Payne, A.I.L., Gulland, J.A. and K.H. Brink, eds., 1987: The Benguela and Comparable Ecosystems. S. African $J$. Mar. Sci. 5, $957 \mathrm{pp}$.

Quinn, W., V. T. Neal and Antunez de Mayolo, 1987: El Niño over the past four and a half centuries. J. Geophys. Res., 92, 14449-14461.

Radovich, J., 1981: The collapse of the California sardine fishery-what have we learned? In: Resource Management and Environmental Uncertainty: Lessons from the Coastal Upwelling Fisheries. M.H. Glantz and J.D. Thompson, eds., Wiley and Sons, New York, 107-136.

Robinson, M.K. and R.A. Bauer, 1976: Atlas of north Pacific Ocean monthly mean temperatures and mean salinities of the surface layer. Naval Oceanographic Office Reference Publication 2. Naval Oceanographic Office, Washington, D.C. 194pp.

Santander, H., 1981: Flucuaciones del desove de anchoveta y algunos factores relacionados. In: Report and Docu- mentation of the Workshop on the Effects of Environmental Variation on the Survival of Larval Pelagic Fishes. G.D. Sharp. ed.. IOC Workshop Rep. Ser. 28 , 255-274, UNESCO, Paris.

and R. Flores, 1983: Los desoves y distribution larval de cuatro especies pelagicas y sus relaciones con las variaciones del ambiente marino frente al Peru. In: Proceedings of the Expert Consultation to Examine Changes in Abundance and Species Composition of Neritic Fish Resources. G.D. Sharp and J. Csirke. eds., F.4O Fish. Rep., 291, 835-870.

Serra, R., 1991: Long-term variability of the Chilean sardine. In: Long-Term Variability of Pelagic Fish Populations. and Their Environment. T. Kawasaki, S. Tanaka. Y. Toba and A. Taniguchi, eds., Pergamon Press. Tokyo, $165-172$.

Sharp. G.D.. 1980: Report of the Workshop on Effects of Environmental Variation on the Survival of Larval Pelagic Fishes. In: Report and Documentation of the Workshop on the Effects of Environmental variation on the Survival of Larval Pelagic Fishes. G.D. Sharp. ed., IOC Workshop Rep. Ser. 28, 1-47, UNESCO, Paris.

, 1987: Climate and fisheries: cause and effect or managing the long and short of it all. In: The Benguela and Comparable Ecosystems. A.I.L. Payne, J.A. Gulland and K.H. Brink, eds., S. African J. Mar. Sci., 5 , 811-838.

, 1988: Neritic systems and fisheries: their perturbations, natural and man induced. In: Ecosystems of the World: Part 27. Continental Shelves. H. Postma and J.J. Zijlstra, eds., Elsevier Scientific Publishing. Amsterdam, 31-48.

and J. Csirke, eds., 1983: Proceedings of the Expert Consultation to Examine the Changes in Abundance and Species Composition of Neritic Fish Resources, San Jose. Costa Rica, 1983. FAO Fish Rep., 291, 1294 pp. and D.R. McLain, 1992: Comments on the global ocean observing capabilities, indicator species as climate proxies, and the need for timely ocean monitoring. Oceanog., 5 163-168.

Soutar, A. and P.A. Crill, 1977: Sedimentation and climatic patterns in the Santa Barbara Basin during the 19th and 20th centuries. Bull. Geol. Sic. Am. 88. 11611172.

Southward, A.J., G.T. Boalch and L. Mattock, 1988: Fluctuations in the herring and pilchard fisheries of Devon and Cornwall linked to change in climate since the $16 \mathrm{th}$ century. J. Mar. Biol. Assoc. UK. 68, 423-445.

Ueber, E. and A. MacCall, 1992: The rise and fall of the California sardine empire. In: Climate l'ariability, Climatc Change and Fisheries. M.H. Glantz, ed., Cambridge University Press, Cambridge, 31-48.

Valdivia, J., 1978: The anchoveta and El Niño. Rapp. P.-I: Reun. Cons. Int. Explor. Mer., 173, 196-202.

Wyatt. T. and M.G. Larrañeta, eds.. 1988: Long Term Changes in Marine Fish populations. Proceedings of a Symposium in Vigo, Spain. 1986. Imprento REAL, Bayona.

Wooster. W.W. and D.L. Fluharty, eds., 1985: El Niño North Niño effects in the Eastern Subarctic Pacific Ocean. Washington Sea Grant program, Seattle. $312 \mathrm{pp}$.

Yañez, E., 1991: Relationships between environmental changes and fluctuating major pelagic resources exploited in Chile (1950-1988). In: Long-Term Variability of Pelagic' Fish Populations and Their Environment. T. Kawasaki. S. Tanaka, Y. Toba and A. Taniguchi, eds., Pergamon Press, Tokyo, 301-309.

Zuta, S.. I. Tsukayama and R. Villanueva, 1984: El ambiente marino y las flucuaciones de las principales poblaciones pelagicas de la costa peruana. In: Proceedings of the Expert Consultation to Examine Changes in Ahundance and Species Composition of Neritic Fish Resources. G.D. Sharp and J. Csirke, eds., F.AO Fish. Rep., 291. 179-254. $\square$ 